\title{
The Effect of a Proposed Educational Program Using Practice Tabulation Forms on Learning Attacking Serving in Volleyball of Girl Students at Faculty of Physical Education
}

\author{
Ahmed Al-Sayed Al-Mowafy Khatab*
}

\begin{abstract}
This study aims to identity the effect of a proposed educational program using practice tabulation forms on learning attacking serving in volleyball of Girl Students at Faculty of Physical Education. The researcher used the experimental method and chose the sample randomly of 60 girl students at forth year of teaching physical education division, volleyball specialization, faculty of physical education- Mansoura university at the first term of the academic year 2011/2012, and the students were divided into (4) equal experimental groups each one included (15 students).

The results of the study showed that the educational program using the mixed practice tabulation ( the distributed \& the massed) under question is more positive and effective in learning attacking serving skill in volleyball than using the other forms of practice tabulation under question. Comparing the (4) groups' results to identify the order preference of the practice tabulation forms in learning attacking serving skill in volleyball, the results showed the following: the form of mixed practice tabulation ( the massed \& the distributed) came at first place, followed by the mixed practice tabulation ( the distributed \& the massed) at the second, then only the distributed practice tabulation at the third, and finally the massed practice tabulation only came at the forth. In the light of these results, the researcher recommends the necessity of using the form of the mixed practice tabulation ( the distributed \& the massed) for its positive effect in learning the attacking serving skill in volleyball of forth year girl Students of teaching physical education division.
\end{abstract}

Keyword: Proposed Educational Program - Practice Tabulation - Attacking Serving - volleybll.

\section{Research introduction and problem}

Volleyball copes with the evolution incident in all the humanities, as this era is witnessing rapid and successive changes result to inventing many ways and methods of learning motor skills of different sports activities in the field of physical education and that requires a physical education teacher who is fully aware of it and studied it accurately and objectively with a comprehensiveness look of what is happening inside the learning processes and what is in the surrounding environment of interactions lead to

* Assistant Professor at Curricula and Methods of Teaching Physical Education Department (Volleyball), Faculty of Physical Education, Mansoura University, Egypt. a total change in behavior and lifestyle.

As there are many methods of learning motor and technical skills used in various sports activities, such as individual learning styles (self) and reciprocity (doubles) and cooperative (collective) or using different forms of education Innovations.... and others, as well as the method of practice tabulation which the researcher found the need to use it specially for it is not used nor spread inadequately in the field of education and training of technical skills in volleyball.

Schmidt 2000 defines style as the executive forms determine rest periods during drawing exercise that must be the first concerns for the 
teacher to schedule exercise and organize it through the modules, and add that in order to access to learning influential should be regulated and scheduling application forms or exercise during the teaching season, learning novice technical skills, whether one skill or two to facilitate the learning process and retention as well as the process of evolution of skillful performance mechanism and avoiding mistakes (16).

Sage 1984 mentioned that key variables of studies concerning practice tabulation is time of the practice and downtime between practices and how to arrange exercises and organize them and it may be required to enter some physical exercises associated with the skill during learning, The distribution of time to practicing learning exercises is one of the factors that helps to learn the performance of these skills the learner performed with a period of rest sets with practice tabulation form (14).

Through the researcher teaching Volleyball for Female Students of Teaching Physical Education division, Mansoura University, he noted the weakness and decline in the level of performance of students for attacking serving skill in volleyball, which may pose several questions as reasons for the emergence of this problem, including: it may be the teaching style, weakness in physical abilities associated with attacking serving skill in volleyball among female students ,may be the attacking serving skill is a hard, or because of arranging and organizing educational steps, may be the periods of work and rest and duplicates, or the method of teaching may be with all of those reasons and others.

The researcher did not only use noting to verify the existence of this problem he has done a preliminary pilot study test using Skills test for the attacking serving skill under study, the pilot study showed that girl students got a rate of $35.5 \%$ of test scores, which showed the weak and decay of attacking serving skill in volleyball.

The thing that made the researcher search for new teaching style that may address such reasons, and having examined many previous studies he did not find a study on the use of forms of practice tabulation forms by either in a volleyball or any other game or sport. The researcher did not either find a study showing preference for any form of practice tabulation, whether the only distributed or only massed or the mixed (distributed - massed) or the mixed (massed - distributed) when learning technical skills in volleyball, this lead to identify the effect of an educational program using practice tabulation forms on learning the skill of attacking serving in volleyball of girl students of Physical Education, Mansoura University, and this is what researcher have for experimentation.

\section{Aim of Research}

The general aim of this study is represented in identifying the effect of a proposed educational program using practice tabulation forms on learning the skill of attacking serving in volleyball of girl students of Physical Education, Mansoura University, through the following subgoals:

1. The effect of a proposed educational program using the method of [Distributed - massed mixed (Distributed - massed) - mixed (massed Distributed)] on learning attacking serving skill in volleyball of girl students in Faculty of Physical Education, Mansoura University.

2. Comparing effect preferences of a proposed educational program using forms of practice tabulation on learning attacking serving skill in volleyball of girl students in Faculty of Physical Education, Mansoura University.

\section{Hypotheses}

1. There are significant differences between the pre and post measurements of the four experimental groups, which used [Distributed massed - mixed(Distributed - massed) - mixed (massed - Distributed)] method on learning attacking serving skill in volleyball for post measurements.

2. There are significant differences between the post measurements of the forms of practice tabulation under discussion on learning attacking serving skill in volleyball of girl students in the Faculty of Physical Education, Mansoura 
University for post measurements of the third experimental group.

\section{Research terms}

1. Practice Tabulation; Defined as "learning sports and physical skills mastering them within training and specialized educational and sequential modules during the week, the month and season, and fully focusing on each educational unit through the implementation of exercise attempts, repeating them and moving to another educational unit to increase exercise and rationing, arranging and organizing loads forms in rest and work periods" (10).

2. The distributed practice tabulation; Defined as "the exercises with breaks for rest between training attempts of the skill required to learn. The rest periods between attempts may be equal or greater than the time taken to complete each attempt that gives greater convenience in the case of relay Exercise" (10).

3. The massed practice tabulation; Defined as "as the process of planning for the distribution of short breaks between periods of activities practicing and educational situations with time that is shorter that the period of practice in the educational unit" (9).

4. The mixed practice tabulation (The distributed \& the massed); Defined as "the process of planning for the distribution of periods of activities practicing and educational situations alternately between long breaks of rest for the first half of practices and short breaks for the last half of practices" (9).

5. The mixed practice tabulation (The massed $\&$ the distributed); Defined as "the process of planning for the distribution of periods of activities practicing and educational situations alternately between short breaks for the first half of practices and long breaks for the last half of practices" (9).

6. Time of application; Defined as "the length of time of motor practicing which is timed and with known repetitions and groups "(3) (12) (15) (8).

7. Downtime; Defined as "a period of time given to the athlete to recover his practical ability to be able to continue practicing the exercise effectively and allows him to return to the natural state, it is also time periods to help him recover his vital energy to further practice activity positively as pulse rate ranges from 110 to 120 beats / minute "(6) (7) (8) (9).

8. Exercise arrangement; Defined as "a serial form regulates the foundations of choosing exercises according to the principles of education and training when designing different programs taking into account the age, gender, individual differences, the sequence of motor skill, gradation from easy to difficult, from simple to complex, from training small muscles first, followed by large muscles, training assistant muscles before basic muscles and from the early stages of compatibility to good compatibility stages " (7).

\section{Procedures of Research}

\section{Method}

The researcher used the experimental method using experimental design with (4) experimental groups with the pre and post measurements of each group; as the first experimental group used distributed practicing tabulation form, the second experimental group used massed practicing tabulation form, the third experimental group used method mixed practice tabulation (Distributed - massed), and the fourth experimental group used mixed practice tabulation (massed - Distributed), so as to appropriateness for the nature of the search.

\section{Sample}

The researcher selected the basic sample randomly, girl students of the fourth year, Division of Teaching Physical Education (Volleyball specialization) Faculty of Physical Education, Mansoura University for the academic year 2011 / 2012, the total number was (60) student, by $(75 \%)$ of the total research community after exclusion, they were divided into (4) equal groups each group was of (15) students, and that was according to the schedule No. (1): 
Table (1)

Research basic sample characterization

\begin{tabular}{|c|c|c|c|c|c|c|c|}
\hline No. & & Research sample & No. & $\begin{array}{l}\text { Form of practice } \\
\text { tabulation }\end{array}$ & $\begin{array}{l}\text { Formation of the } \\
\text { load } \\
\text { (action : rest) }\end{array}$ & total & $\begin{array}{l}\text { Sample percent of } \\
\text { community }\end{array}$ \\
\hline 1 & \multirow{4}{*}{ 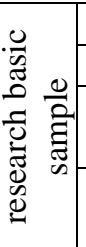 } & First experimental group & 15 & distributed & $(1: 1)$ & \multirow{4}{*}{60} & \multirow{4}{*}{$75 \%$} \\
\hline 2 & & second experimental group & 15 & massed & $(2: 1)$ & & \\
\hline 3 & & third experimental group & 15 & $\begin{array}{l}\text { Mixed (Distributed - } \\
\text { massed) }\end{array}$ & $(1: 1)-(2: 1)$ & & \\
\hline 4 & & fourth experimental group & 15 & $\begin{array}{l}\text { Mixed (massed - } \\
\text { Distributed) }\end{array}$ & $(2: 1)-(1: 1)$ & & \\
\hline 5 & & Exploratory sample & 20 & \multicolumn{3}{|c|}{$\begin{array}{c}\text { Rationing program to calculate tests reliability and } \\
\text { validity under discussion }\end{array}$} & $25 \%$ \\
\hline & & Total & 80 & \multicolumn{3}{|c|}{-} & $100 \%$ \\
\hline
\end{tabular}

\section{Methods of data collection}

Through Reference scanning for specialized foreign Arabic studies and in the field of Volleyball the researcher got to reach skill tests that measure skill under discussion:

- Diametrical attacking serving from center 4 to center 5, (6).

- Straight attacking serving from center 4 to center $1,(10)$.

\section{Pilot studies under discussion}

\section{The first pilot study}

The researcher conducted this study in the period from 24/09/2011 to 28/9/2011, on (8) of the fourth year students at Faculty of Physical Education, Mansoura University, a similar sample to the research sample and outside of the core sample in order to find reliability coefficient for skillful tests under discussion. The results of this study is finding the value of reliability coefficient of the tests of skill under discussion, as they reached (0.913 - 0.920), through the application of the test and reapplication of the test (Test - Retest) in the same conditions of the first application in the same time and place and with the same tools for the possibility of tuning variables.

\section{The second pilot study}

The researcher conducted this study in the period from $1 / 10 / 2011$ to $5 / 10 / 2011$ on (8) Features girl students (those with a high level) and the participants in the Faculty of Physical Education volleyball team Mansoura University, in order to calculate the true differentiation factor for skillful tests under discussion. The results of this study lead to identifying validity coefficient for the tests in question.

\section{The third pilot study}

The researcher conducted this study in the period from $8 / 10 / 2011$ to $13 / 10 / 2011$, on (8) fourth year students at the Faculty of Physical Education Mansoura University, a similar sample to the research sample and outside of the core sample, and the objectives of this study are:

1. Determining the places where the application of the basic experiment will be held.

2. Making sure of the validity of the used instruments and devices under discussion before the application of the basic experiment.

3. Determining the basics of the proposed educational program to reach the final shape through:

- Rationing the proposed educational program by selecting the time of performance and rest of each form of practice tabulation.

- Determining the time of educational steps that can be applied during the time allocated for lecture $=(120)$ minutes and according to the school schedule, including the parts of the unit of warm-up, a major part, and a closing part of the program under discussion.

The results of this study proved achieving its objectives, and the researcher managed out a number of results through which he reached the final form of the proposed educational program using the method of practice tabulation forms, as well as overlapping variables which may affect the basic experience with the possibility of adjusting them. 


\section{Executive search steps}

\section{Pre measurement}

Pre measurements were made on research basic sample by applying the tests of the variables (under discussion) in the period from Saturday 15/10/2011, until Thursday, 20/10/2011.

\section{Research basic experience}

The proposed educational program under discussion was applied on the four experimental groups, by (4) weeks, (2) units per week and the time of the unit $(120 \mathrm{~m})$ on Sundays and Wednesdays of each week, and that was in the period from Sunday 30/10/2011, until Wednesday, 23/11/2011.

\section{Post measurement}

Post measurements of the variables (under discussion) were made in the same way and arrangement of pre measurements after the application of the program directly, in the period from Saturday 26/11/2011, until Thursday, 1/12/2011.

\section{Result}

Table (2)

Significant differences between pre and post measurements of the (4) experimental groups $N 1=N 2=N 3=N 4=15$

\begin{tabular}{|c|c|c|c|c|c|c|c|c|}
\hline \multirow[b]{2}{*}{ groups } & \multirow[b]{2}{*}{ Variables } & \multirow{2}{*}{ 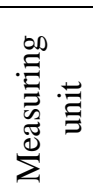 } & \multicolumn{2}{|c|}{ Pre measurement } & \multicolumn{2}{|c|}{ Post measurement } & \multirow[b]{2}{*}{$\begin{array}{c}\mathrm{T} \\
\text { value }\end{array}$} & \multirow[b]{2}{*}{$\begin{array}{l}\text { Improving } \\
\text { percentage }\end{array}$} \\
\hline & & & Mean & deviation & Mean & deviation & & \\
\hline \multirow{2}{*}{$\begin{array}{l}\text { First } \\
\text { experimental } \\
\text { group }\end{array}$} & $\begin{array}{c}\text { Diametrical attacking } \\
\text { serving from center } 4 \text { to } \\
\text { center } 5\end{array}$ & \multirow{2}{*}{ 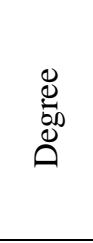 } & 4.133 & 1.125 & 12.4 & 1.595 & $\begin{array}{c}20.268 \\
*\end{array}$ & $200.0 \%$ \\
\hline & $\begin{array}{c}\text { straight attacking } \\
\text { serving from center } 4 \text { to } \\
\text { center } 1 \\
\end{array}$ & & 2.733 & 1.438 & 12.2 & 1.568 & $\begin{array}{c}15.764 \\
*\end{array}$ & $346.3 \%$ \\
\hline \multirow{2}{*}{$\begin{array}{l}\text { second } \\
\text { experimental } \\
\text { group }\end{array}$} & $\begin{array}{c}\text { Diametrical attacking } \\
\text { serving from center } 4 \text { to } \\
\text { center } 5 \\
\end{array}$ & \multirow{2}{*}{ 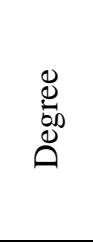 } & 3.733 & 1.668 & 10.800 & 2.678 & $\begin{array}{c}9.162 \\
*\end{array}$ & $189.3 \%$ \\
\hline & $\begin{array}{c}\text { straight attacking } \\
\text { serving from center } 4 \text { to } \\
\text { center } 1 \\
\end{array}$ & & 2.467 & 1.060 & 11.067 & 1.710 & $\begin{array}{c}20.887 \\
*\end{array}$ & $348.6 \%$ \\
\hline \multirow{2}{*}{$\begin{array}{l}\text { third } \\
\text { experimental } \\
\text { group }\end{array}$} & $\begin{array}{c}\text { Diametrical attacking } \\
\text { serving from center } 4 \text { to } \\
\text { center } 5 \\
\end{array}$ & \multirow{2}{*}{ 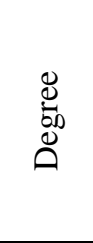 } & 3.600 & 1.882 & 14.733 & 1.580 & $\begin{array}{c}15.841 \\
*\end{array}$ & $309.3 \%$ \\
\hline & $\begin{array}{c}\text { straight attacking } \\
\text { serving from center } 4 \text { to } \\
\text { center } 1\end{array}$ & & 2.533 & 1.125 & 13.533 & 1.407 & $\begin{array}{c}30.125 \\
*\end{array}$ & $434.3 \%$ \\
\hline \multirow{2}{*}{$\begin{array}{l}\text { fourth } \\
\text { experimental } \\
\text { group }\end{array}$} & $\begin{array}{l}\text { Diametrical attacking } \\
\text { serving from center } 4 \text { to } \\
\text { center } 5 \\
\end{array}$ & \multirow{2}{*}{ 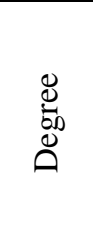 } & 3.400 & 1.298 & 13.000 & 1.604 & $\begin{array}{c}19.753 \\
*\end{array}$ & $282.4 \%$ \\
\hline & $\begin{array}{c}\text { straight attacking } \\
\text { serving from center } 4 \text { to } \\
\text { center } 1 \\
\end{array}$ & & 2.733 & 1.163 & 12.467 & 1.356 & $\begin{array}{c}20.164 \\
*\end{array}$ & $356.2 \%$ \\
\hline
\end{tabular}


Figure (1)

Significant differences between pre and post measurements of the (4) experimental groups

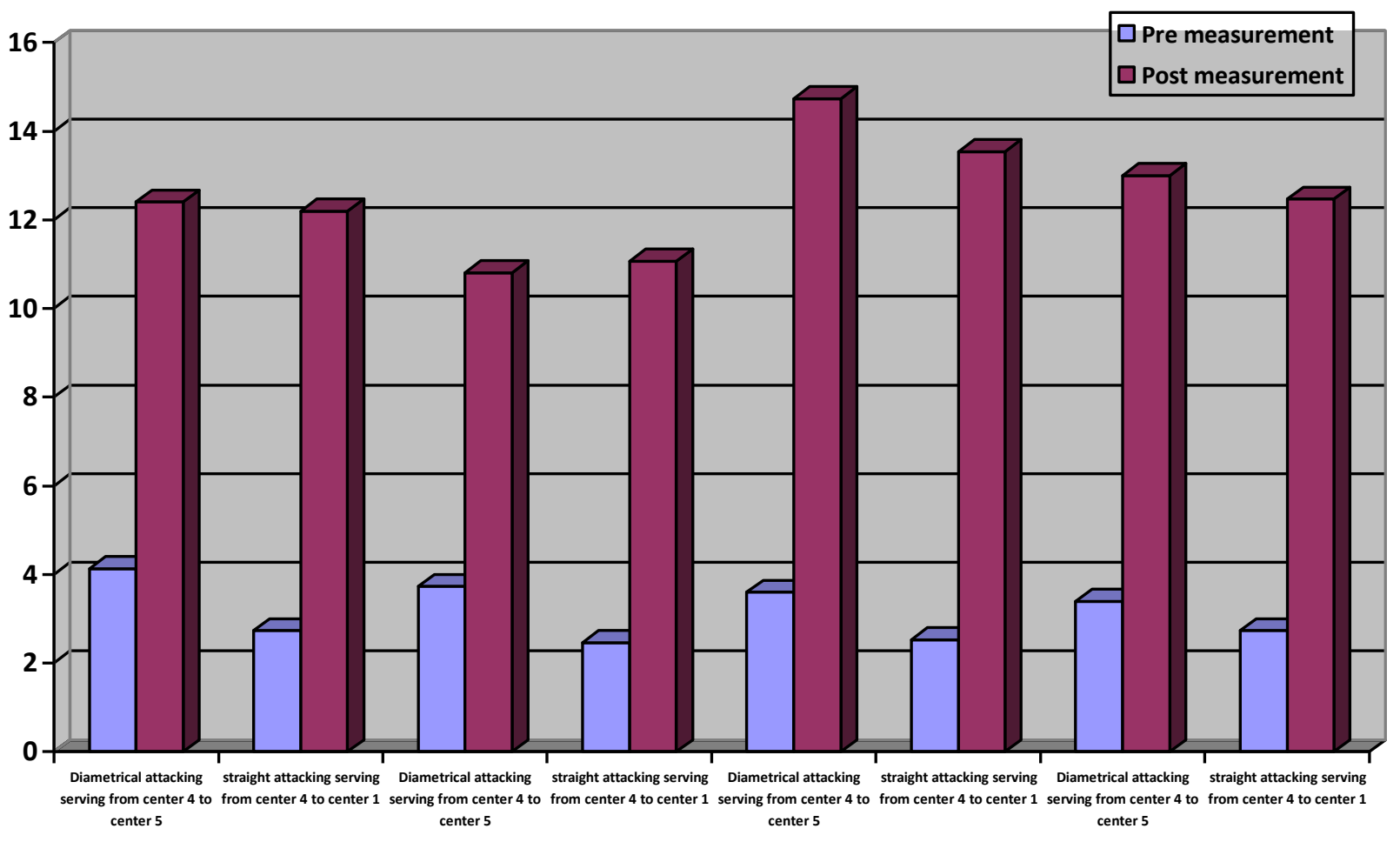

* Coefficient $(T)$ value $/ 0.05=2.145$.

Table (3)

Significant differences between pre measurements of the (4) experimental groups $N 1=N 2=N 3=N 4=15$

\begin{tabular}{|c|c|c|c|c|c|c|}
\hline Variables & 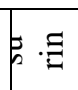 & groups & $\begin{array}{c}\text { Total of the } \\
\text { squares }\end{array}$ & $\begin{array}{c}\text { Degree of } \\
\text { freedom }\end{array}$ & Contrast & $\begin{array}{l}\text { Value } \\
(\mathrm{F})\end{array}$ \\
\hline \multirow{3}{*}{$\begin{array}{c}\text { Diametrical attacking serving from } \\
\text { center } 4 \text { to center } 5\end{array}$} & \multirow{3}{*}{$\begin{array}{l}\stackrel{\Xi}{\circlearrowright} \\
\stackrel{.0}{0} \\
\stackrel{D}{0}\end{array}$} & $\begin{array}{c}\text { Between } \\
\text { groups }\end{array}$ & 118.8 & 3 & 39.6 & \multirow{3}{*}{$\begin{array}{c}10.716 \\
*\end{array}$} \\
\hline & & Inter groups & 206.933 & 56 & 3.695 & \\
\hline & & Total & 325.733 & 59 & - & \\
\hline \multirow{3}{*}{$\begin{array}{c}\text { straight attacking serving from center } 4 \\
\text { to center } 1\end{array}$} & \multirow{3}{*}{ 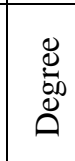 } & $\begin{array}{c}\text { Between } \\
\text { groups }\end{array}$ & 46.183 & 3 & 15.394 & \multirow{3}{*}{$6.693 *$} \\
\hline & & Inter groups & 128.8 & 56 & 2.3 & \\
\hline & & Total & 174.983 & 59 & - & \\
\hline
\end{tabular}

* Correlation coefficient $(F)$ value / $0.05=2.710$ 
Table (4)

Value L.S.D

\begin{tabular}{|c|c|c|c|c|c|c|c|c|}
\hline \multirow[b]{2}{*}{ Variables } & \multirow[b]{2}{*}{ 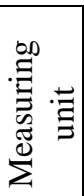 } & \multirow[b]{2}{*}{ groups } & \multirow[b]{2}{*}{ Mean } & \multicolumn{4}{|c|}{ differences between groups } & \multirow[b]{2}{*}{$\begin{array}{l}\text { Value } \\
\text { L.S.D }\end{array}$} \\
\hline & & & & $\begin{array}{l}\text { First } \\
\text { experimental } \\
\text { group }\end{array}$ & $\begin{array}{l}\text { second } \\
\text { experimental } \\
\text { group }\end{array}$ & $\begin{array}{l}\text { third } \\
\text { experimental } \\
\text { group }\end{array}$ & $\begin{array}{l}\text { fourth } \\
\text { experimental } \\
\text { group }\end{array}$ & \\
\hline \multirow{4}{*}{$\begin{array}{l}\text { Diametrical } \\
\text { attacking } \\
\text { serving from } \\
\text { center } 4 \text { to } \\
\text { center } 5\end{array}$} & \multirow{4}{*}{$\begin{array}{l}\mathscr{D} \\
\stackrel{0}{0} \\
\stackrel{\mathscr{D}}{0}\end{array}$} & $\begin{array}{l}\text { First experimental } \\
\text { group }\end{array}$ & 12.4 & - & $1.6 *$ & - & - & \multirow{4}{*}{1.512} \\
\hline & & $\begin{array}{l}\text { second } \\
\text { experimental } \\
\text { group }\end{array}$ & 10.8 & - & - & - & - & \\
\hline & & $\begin{array}{l}\text { third experimental } \\
\text { group }\end{array}$ & 14.733 & $2.333 *$ & $3.933 *$ & - & $1.733 *$ & \\
\hline & & $\begin{array}{l}\text { fourth } \\
\text { experimental } \\
\text { group }\end{array}$ & 13.000 & 0.6 & $2.2 *$ & - & - & \\
\hline \multirow{4}{*}{$\begin{array}{c}\text { straight } \\
\text { attacking } \\
\text { serving from } \\
\text { center } 4 \text { to } \\
\text { center } 1\end{array}$} & \multirow{4}{*}{ 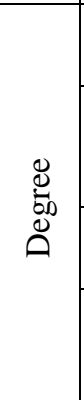 } & $\begin{array}{l}\text { First experimental } \\
\text { group }\end{array}$ & 12.2 & - & 1.133 & - & - & \multirow{4}{*}{1.192} \\
\hline & & $\begin{array}{l}\text { second } \\
\text { experimental } \\
\text { group }\end{array}$ & 11.067 & - & - & - & - & \\
\hline & & $\begin{array}{l}\text { third experimental } \\
\text { group }\end{array}$ & 13.533 & $1.333 *$ & $2.466 *$ & - & 1.066 & \\
\hline & & $\begin{array}{l}\text { fourth } \\
\text { experimental } \\
\text { group }\end{array}$ & 12.467 & 0.267 & $1.4 *$ & - & - & \\
\hline
\end{tabular}

* = Significance

Figure (2)

Significant differences between pre measurements of the (4) experimental groups

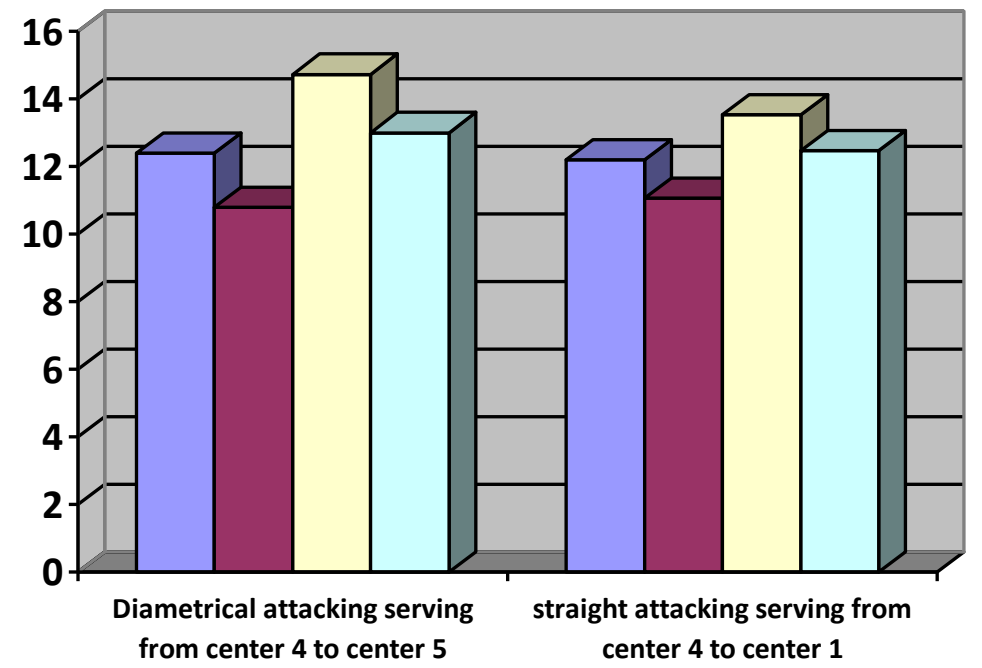

\begin{tabular}{|l|}
$\square$ First experimental group \\
$\square$ second experimental group \\
$\square$ third experimental group \\
$\square$ fourth experimental group
\end{tabular}

\section{Discussion of the results}

In light of the results which have been obtained and presented in tables (2) and Figure No. (1), it was clear that there is a statistically significant difference between the pre and post and measurements for post measurement of each of the (4) groups within research. The researcher attributes the reasons of the positive effect for using the method of practice tabulation in its various forms [only distributed, only massed, (Distributed - massed), (massed - Distributed)] under discussion, because the rest periods between iterations within the educational program gave an opportunity for the students to review their performance mentally and realize their motor duty, and kept them away from fear, fatigue and boredom, which hits them if they were deprived from their rest period making 
them focus better on learning the skillful performance of attacking serving skill in volleyball.

The results of this study comes with what Amerallah Ahmed Bisatti in 1998, and Bastawisy Ahmed 1999, Mufti Ibrahim Hammad, 1999 referred to that there is a similarity between the symptoms of fatigue and fear with a positive relationship to treat them and that would be with periods of positive rest. Fatigue is known as a "relative timed drop in the level of functional capacity due to consumption of energy sources in the muscles and the increase of remains resulting from fatigue as a result of lack of oxygen. It is a life physiological organic psychological defensive phenomenon causes low functional capacity as a result of exposure to external pressures protecting members and internal organs from damage during work ". All of these definitions clarify that fatigue is relationships of running out of energy stored within the body and an indicator to the effect of the external action on the nervous, muscular system and other functional systems within the body. Fatigue can also be an indicator through which the level of endurance can be inferred and its forms the learner implements through the educational or training units. The proper relationship between exercise loads performing periods and rest periods is which happens after it an adjustment for members and organs of the body through the balance between operations of demolition and construction; and the treatment of fatigue is to give appropriate rest periods with the effort made by the learner and according to the type and difficulty of the exercise (3) (4) (11).

The researcher believes that beginners in volleyball need organized time to rest between iterations and during them, because the transition from easy educational steps to difficult steps is not easy for them. As there is a difficulty in the application they did not suffer in former performance, as well as organizing and arranging working and rest hours facilitates motor performance. With a comfort interfaces for duplicates and quality and physical exercise make students performing more accurately and balanced controlling their physical and kinetic abilities and their mental readiness to do easy performance and move with its effect on difficult performance through the proper mindset motor track from the beginning stages of skill to end.

Both Sage 1984, and Schmidt 2000, Wajih Mahjoub 2002, Indicate that practice tabulation forms gives the learner time to recover and strengthen acquisition early through practices distributed to motor duties and think in the correct performance of the skill through breaks between a frequency and another, as well as giving appropriate feedback to review motor efficiency mentally of the skill to be learned (14) (16) (18).

Those results agree with the studies of each of Tariq Nizar majid Al-Talb in 2001 (17), Laith Mohammed Daoud al-Banna in 2001 (9), Gabriel Ojerid Oudat, 2004 (5), Novell Fadel Rashid, 2005 (13), the superiority of research groups in post measurement over pre measurement of variables under question which reflected the effectiveness and positive effect of practice tabulation forms.

The thing that proves the validity of first hypothesis, which is "There is statistically significant differences between the pre and post measurements of the four experimental groups, which use practice tabulation forms [ only Distributed - only massed - mixed(Distributed massed) - mixed (massed - Distributed)] under discussion to learn attacking serving skill in volleyball for post measurements of the (4) groups ".

In light of the results which have been obtained and presented in tables $(3,4)$ and Figure No. (2); it became clear that there are statistically significant differences between the post measurements of (4) experimental groups under discussion in favor of the third group, which used a method of mixed practice tabulation (Distributed - massed). The researcher attributes the causes of positive effect of this form from other forms that educational program using the method of mixed practice tabulation (Distributed - massed) patronized between types of rest periods and work to form loads ranging from medium intensity that move to high intensity suited with the most difficult skills of volleyball which is attacking serving helping Students at the beginning of the module to acquire as much information about the skill and its performance rapidly this which made them reduce making errors. The fact that they have 
the right foundation for the kinetic path made them progressed in performing exercises and enabled them to control the types of applications in the educational unit itself and throughout the tutorial, overcoming primitive difficulties to gain information as the distributed duplicates were of medium loads at the beginning of each exercise in the module until they were turned into intense duplicates of highest loads were enough to build a track and progress of attacking serving skill in volleyball under discussion.

The results of this study are consistent with what both Abo ualala Ahmed Abdel Fattah, and Mohamed Sobhy Hassanein, 1997 indicated that the gradation in load components and its relationship to rest periods promise the most important factors for the high level of sports achievement and development, as the relying on increasing the volume of training load remained for a long time the most important factor in the effect. Researchers then turned to increasing the effectiveness of the training load by calculating the relationship between the components and the rest periods with ensuring not reaching fatigue or stress in order to reach high sports levels (2).

The researcher believes that mergers and intervention form holds other forms creates a state of progress and development as a result of the exploitation of positive specifications of each method, and using them in one manner would increase the learning skill well and appropriately, as the skill of attacking serving volleyball is difficult and needs to overcome the factor of fatigue as a result of iterations, using force and appropriate quality and physical exercise as well as compatibility neuromuscular and controlling body posture before, during and after the performance. Reducing the difficulties has been done properly in the use of distributed applications at the beginning of the module. This has given enough time to retrieve the perception of mental information when performing exercises, and controlling them in massed applications in the latter half of the module, which led to the control of the factor of syndrome and physical fatigue and the information which were obtained through the following response that the students could acquired and stored during the rest periods that characterized the distributed application at the beginning of the module. This in turn led to know the results or feedback and correct misinformation.

According to both Yaarb Khyoun 2002 and Abdullah Hussein al-Lami, 2006 the basic principle that determines the learning process of distributed, massed or mixed style is rest time between an exercise and another or between the repetitions of each exercise as the distributed exercise means having complete enough rest between repetitions reverse massed exercise in which less or no rest periods. A teacher or a coach can manipulate times of rest between an attempt and another, may be in three attempts, or may be in five attempts... Thus (19) (1).

Both Sage 1984, Schmidt 2000, Indicate that the form of mixed practice tabulation (Distributed massed) is the process of planning for the distribution of exercising activities periods and educational situations alternately between long rest periods of the first half of practices and short rest periods for the other half of practices. The process of learning for individual is characterized in the early stages with gaining any certain skillful style with variations and differences of responses. The whole body tends to increase muscle tension, and novice learner faces difficulties in the performance of many of the movements, therefore it is our duty that early lessons not to be complex or difficult. Also, fast learning and repetition does not lead to increased learning, but it may increase or prove motor errors through performing skills. Repetition in the position of education can also change and alter learning in way that was not intended or required. Practice and distributed drills achieves better performance rate in the early stages of education While massed achieve better rate in the final stages of the education process. As the gradually diminishing in the long periods of training during the learning phase drives to the increase of learning effectiveness, and it is possible to enhance the early acquisition through distributed practices while late acquisition is when exercises are focused. Merging or overlapping between the number of tabulation practices have a positive effect in getting the process of learning motor skills in various team sports (16) (14). 
This is consistent with what Schmidt, 2000 referred to that teachers are supposed to encourage learners to perform the largest possible number of attempts to exercise as much as possible, also the distribution of the training load and gradation to match the level of the sample as well as exercises that took space of time of educational or training unit. Diversification in the use of exercise led to the removal of boredom form learners and pushing them seriously towards the best performance according to the fact that various exercises make the player eager to education, training and motivating different muscle groups depending on the type of exercise (16).

The results of this study agree with the results of a study Tariq Nazar Majeed taleb 2001 (17), the superiority of mixed practice tabulation (Distributed - massed) in variables under dissection, which reflected the positive effect of this form from the rest of the practice tabulation forms.

The thing that achieves the validity of the second hypothesis, which is "There are statistically significant differences between post measurements of the practice tabulation forms in question in learning attaching serving skill in volleyball of girl students at Faculty of Physical Education, Mansoura University, in favor of post measurements of the third experimental group."

\section{Conclusions}

- Practice tabulation forms : distributed - massed - mixed (Distributed - massed) - mixed (massed - Distributed) were more effective and the effect on learning attacking serving skill in volleyball of girl students in the Faculty of Physical Education, Mansoura University.

- Preference of the effect of practice tabulation forms when learning attacking serving skill in volleyball for the sample under discussion as follows:

* mixed practice tabulation (Distributed massed) form ranked first.

* followed in second rank with mixed practice tabulation variable (massed - Distributed) form.

* then in third place practice tabulation form (only distributed).
* finally in fourth place practice tabulation form (only massed).

\section{Recommendations}

- Applying using the form of mixed practice tabulation (Distributed - massed) for his positive effect on outcomes of learning attacking serving skill in volleyball of the Fourth Grade girl Students at Teaching Physical Education Division.

- Doing further studies using practice tabulation forms on the rest of the technical skills in volleyball in particular and the rest of the team and individual sports in general.

\section{References}

1. Abdullah Hussein al-Lami (2006): Fundamentals of motor learning, part.1, art supporter group, University of Qadisiyah, p. 91.

2. Abo Ela Ahmed Abdel Fattah, Mohamed Sobhy Hassanein (1997): Physiology and morphology sport and measurement methods for evaluation, Arab Thought House, Cairo. p. 76.

3. Amrallah Ahmed AlBsaty (1998): Rules and the fundamentals of sports training and its applications, knowledge facility - Alexandria, p. 54.

4. Bastawisi Ahmed (1999): foundations and theories of sports training, the Arab Thought House - Cairo, p. 177.

5. Gabriel Ojerid Ouda ( 2004): The effect of using some methods of practice tabulation in learning the technical performance and improving achievement for some shooting competitions, unpublished Ph.D. thesis, Faculty of Physical Education, University of Mosul, Jordan. P. 213.

6. Jhon Kessell (1997) : Coaching youth Volley ball, second Edition, U.S.A. p. 67 - 69.

7. http://www.iraqacad.org/Lib/adil/acad1.htm $(23 / 12 / 2012)(5 \mathrm{am})$.

8. http://drsphinx26.wordpress.com. (22/12/2012) (3.30 am).

9. Laith Mohammed Daoud al-Banna (2001): The effect of using the daily practice tabulation 
of educational unit to acquire and preserve the art of performance and accuracy of some easy and difficult transmissions in volleyball, unpublished Ph.D. thesis, Faculty of Physical Education, Mosul University, Jordan. P. 187.

10. Mary Wise (1999) : Volley ball Drills for champions, university of Florida, eidtor, Human Kinetics, U.S.A. p. $72-75$.

11. Mufti Ibrahim Hammad (1999): the modern sports training planning, implementation and leadership, part.1, Arab Thought House for Printing and Publishing - Cairo, p. 1.

12. Nashwan Ibrahim Abdallah AlNemei (2004): Impact of overload phenomenon and natural and high temperature on some variables of immune system, unpublished doctoral thesis, Mosul University, p. 318.

13. Novell Fadel Rashid (2005): The effect of using some methods of practice tabulation of physical and skillful level and cognitive acquisition in a football, unpublished Ph.D. thesis, Faculty of Education, Sports, Mosul University, Jordan. P. 146.
14. Sage H. (1984) : " Motor Learning and control aneuro psychological approach, WMC . Brown publishers lowa , U. S. A . p. $290-$ 419.

15. Satea Esmail (2007): fatigue, a serious of lectures on the internet, Iraqi sports electronic academy, p. 135.

16. Schmidt A. Richard (2000): " Motor Learning and Performance" Human Kinetics Books, champing, Ilion's . p. 86-215.

17. Tariq Nazar Majeed Taleb (2001): The effect of using exercising massed and distributed forms in learning and transferring learning some gymnastics skills, unpublished Ph.D. thesis, Faculty of Physical Education, University of Baghdad, Iraq. P. 218.

18. Wajih Mahjoub (2002): Learning and education and mobility programs, Dar Al-Feker for printing, publishing and distribution, Amman, Jordan. P. 89.

19. Yaarb Khyoun (2002): motor learning between principle and practice, the Office of the Rock for printing, Baghdad, p. 85. 